\title{
Trends in Plasma Toll Fractionation for Self Sufficiency of Plasma-Derived Medicinal Products in Italy
}

\author{
Vincenzo De Angelis ${ }^{a}$ Antonio Breda ${ }^{b}$

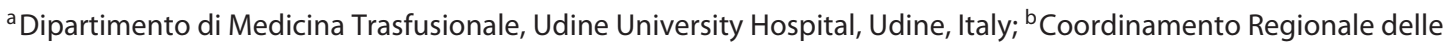 \\ Attività Trasfusionali, Conegliano, Italy
}

\section{Keywords}

Plasma products · Self-sufficiency · Toll manufacturing · Clinical governance

\begin{abstract}
Background and Aims: In Italy, domestic plasma toll fractionation, performed until 2014 by only one company, had limited access to different technologies and products and to price competition. In 2017, four companies acted as competitive toll fractionators for $827,720 \mathrm{~kg}$ of plasma. Here, we evaluate the contribution of toll manufacturing and the effects of competition on national self-sufficiency. Results: An increase in immunoglobulin production is granted by new fractionators (11-41\%, in some regions adequate for self-sufficiency), although the rise in demand will still require market contribution. The decrease in albumin use (-2.6\% in 2015 vs. 2014) is probably due to a better control of an impressively high demand (35.4 t in 2015). Factor VIII demand is still higher than production, but domestic plasma cannot serve as its unique source. New tenders enlarged the portfolio of products and a theoretical self-sufficiency is granted for Factor IX, prothrombin complex concentrates, antithrombin, fibrinogen, and alpha-1-antithrypsin. Conclusions: Competition among companies resulted in higher yields of albumin and immunoglobulin, decreasing their level of market dependence, an increase in the portfolio of medicines, and a decrease in price due to fractionation (20-30\%), thus improving perspectives of the national program for self-sufficiency in plasma-derived medicinal products.

๑) 2019 S. Karger AG, Basel
\end{abstract}

(C) 2019 S. Karger AG, Basel

\section{Introduction}

Toll plasma fractionation is understood to mean an arrangement in which a licensed pharmaceutical company processes human plasma collected by blood establishments into medicinal products for use within a country. This is the only possible way in Italy to fractionate into medicinal products plasma collected and tested from voluntary nonremunerated donors (VNRDs) by Italian transfusion services, which are not allowed, by law, to sell plasma to fractionators. There is not a unique national tender but one region runs the contract on behalf of many others, a partnership needed to reach adequate volumes of plasma to be fractionated. This is finalized at national self-sufficiency for blood products, as required by the national legislation [1].

Until 2014 only one pharmaceutical company was allowed to sign contracts with Italian regions. The lack of competition was a limit to the extent of toll manufacturing. Due to the lack of possibility to access technologies and products of different companies, the exchange among regions was restricted to a few surplus products and there was no price competition for the service. After the Ministerial Decree of December 5, 2014 [2] came into force, the following pharmaceutical companies have been identified as competitive fractionators: Baxter Manufacturing (now Shire, Rieti, Italy), CSL Behring (Bern, Switzerland), Grifols (Barcelona plant, Spain), Kedrion (Bolognana, Gallicano, Italy), and Octapharma (Stockholm, Sweden). Following the modification of the legal framework [3], 
Table 1. Main characteristics of the four groups of Italian regions

\begin{tabular}{|c|c|c|c|c|c|c|}
\hline Partnership & $\begin{array}{l}\text { Population, } n \\
\text { (\% of national } \\
\text { total) }\end{array}$ & Tender & Fractionator & $\begin{array}{l}\text { Plasma for } \\
\text { fractionation } \\
\text { in } 2017, \mathrm{~kg}\end{array}$ & $\begin{array}{l}\% \text { of Italian } \\
\text { production }\end{array}$ & $\begin{array}{l}\text { kg per } 1,000 \\
\text { inhabitants } \\
\text { in } 2017\end{array}$ \\
\hline $\begin{array}{l}\text { NAIP (Abruzzo, Basilicata, Friuli V.G., Liguria, } \\
\text { Trentino - Alto Adige, Umbria, Aosta Valley, } \\
\text { Veneto) }\end{array}$ & $11,661,971(19)$ & $\begin{array}{l}\text { Awarded / } \\
\text { contract operating }\end{array}$ & CSL Behring & 194,993 & 24 & 16.7 \\
\hline RIPP (Emilia-Romagna, Calabria, Puglia, Sicily) & $15,534,498(26)$ & Awarded & $\begin{array}{l}\text { Kedrion and } \\
\text { Grifols }\end{array}$ & 206,067 & 25 & 13.3 \\
\hline $\begin{array}{l}\text { PLANET (Tuscany, Campania, Lazio Marche, } \\
\text { Molise) }\end{array}$ & $17,328,149(29)$ & Awarded & $\begin{array}{l}\text { Baxter/ } \\
\text { Baxalta }\end{array}$ & 181,536 & 22 & 10.3 \\
\hline ACCORDO (Lombardy, Piemont, Sardinia) & $16,064,827(26)$ & Not awarded & $\begin{array}{l}\text { Kedrion } \\
\text { (previous contract) }\end{array}$ & 245,126 & 29 & 15.3 \\
\hline Italy & $60,589,445$ & & & 827,720 & & 13.7 \\
\hline
\end{tabular}

tenders have been finalized to fractionate Italian plasma by different companies, with interesting results capable of improving, in a substantial way, perspectives of the national program for self-sufficiency in plasma-derived medicinal products (PDMPs). Together with the increase in yield of some proteins, the competition is expected to increase the portfolio of products sourced from national plasma. Here, we try to evaluate the effective contribution of medicinal products from toll manufacturing of domestic plasma to their national self-sufficiency, and to explore some scenarios expected in Italy in the coming years.

\section{Plasma Production and Fractionation in Italy}

With $827,720 \mathrm{~kg}$ of plasma collected in 2017 (26\% from apheresis and the remaining recovered), Italy is the second most productive European country for volume of plasma fractionated (following Germany and together with France), and the fractionation rate is $13.7 \mathrm{~kg} / 1,000$ inhabitants [4]. However, there is a pronounced difference within the country, with regions collecting plasma for fractionation up to $22 \mathrm{~kg}$ per 1,000 inhabitants and others around $4 \mathrm{~kg}$ per 1,000 inhabitants. This discrepancy has prompted a Ministerial Decree [5] planning the improvement of plasma collection through the maintenance of good performance in high-productivity regions while increasing production in low-performance areas, and aiming to reach a rate of collection of $16-17 \mathrm{~kg} / 1,000$ inhabitants by 2020 (Table 1 ).

The main feature of the Italian toll manufacturing is that plasma, intermediates, and products always remain a property of the regions: plasma from blood establishments is sent to a pharmaceutical company which is paid for its fractionation in a separate cycle and for distribution to the regions of all medicines derived from the process. At present, agreements are in place involving four partnerships among different Italian regions: the AC-
CORDO group, the NAIP (Nuovo Accordo Interregionale Plasma) group, the PLANET (Plasma Network) group, and the RIPP (Raggruppamento Interregionale Plasma Produzione) group. Agreements are intended to achieve a critical mass of plasma to be fractionated, estimated at between 150,000 and $250,000 \mathrm{~kg}$ of plasma per year, in order to guarantee the continuous production and distribution of PDMPs. In fact, although in principle a contract fractionation program can require volumes as small as 30,000-50,000 kg per year, these volumes may present technical and economical drawbacks, because in the event of a batch failure a substantial proportion of the national need would be lost and the regular supply of products would be compromised. On the other hand, larger volumes (more than $250,000 \mathrm{~kg}$ ) restrict the number of companies with sufficient capacity and require contingency plans to reduce risks of product shortage in case of problems at the fractionation plant [6]. Finally, tenders made by regional partnerships are expected to lower the cost of the service.

Table 1 summarizes the characteristics (population, state of the tender after opening to competition, and present fractionator) and data on plasma collection in the 4 groups of regions (total and standardized kilograms per 1,000 inhabitants) for 2017 and the expected increase (\%) in 2020, according to the national plasma plan.

\section{Plasma Products from Toll Manufacturing in Italy}

Data presented herein come from the last available report published by a governmental source (National Health Institute) and refer to the year 2015 [7]. They are summarized in Table 2 (plasma production, price for fractionation, product demand, and rate of self-sufficiency) for driving products (albumin and immunoglobulin; Ig), and in Table 3 (plasma production needed to meet the demand) for accessory products. 
Table 2. Plasma production (kg), protein yield (Ig and albumin), product demand, and rate of self-sufficiency in the four partnerships of regions

\begin{tabular}{|c|c|c|c|c|c|c|c|c|c|c|}
\hline \multirow[t]{2}{*}{$\begin{array}{l}\text { Partnership of regions } \\
\text { and fractionator }\end{array}$} & \multirow{2}{*}{$\begin{array}{l}\text { Price for } \\
\text { fractionation, } \\
\text { EUR/kg }\end{array}$} & \multicolumn{2}{|c|}{ Yield, g/kg } & \multicolumn{2}{|c|}{2015 demand, $g$} & \multirow{2}{*}{$\begin{array}{l}\text { Plasma for } \\
\text { fractionation } \\
\text { in 2017, kg }\end{array}$} & \multicolumn{2}{|c|}{$\begin{array}{l}\text { Plasma needed for } \\
\text { self-sufficiency, kg }\end{array}$} & \multicolumn{2}{|c|}{$\begin{array}{l}\text { Present \% of } \\
\text { self-sufficiency }\end{array}$} \\
\hline & & albumin & Ig & albumin & $\operatorname{Ig}$ & & albumin & Ig & albumin & Ig \\
\hline NAIP (CSL Behring) & 94.60 & 25.0 & 4.9 & $5,105,358$ & 931,743 & 194,993 & 204,214 & 190,152 & 95 & 103 \\
\hline RIPP (Kedrion/ Grifols) & 118.00 & 26.0 & 4.1 & $8,880,723$ & $1,093,923$ & 206,067 & 341,435 & 266,810 & 60 & 77 \\
\hline PLANET (Baxter/Baxalta) & 99.85 & 25.3 & 5.0 & $11,984,644$ & $1,416,880$ & 181,536 & 473,701 & 283,376 & 47 & 64 \\
\hline Italy & & & & $35,374,743$ & $4,634,308$ & 827,720 & $1,377,893$ & $1,162,000$ & 66 & 77 \\
\hline
\end{tabular}

Table 3. Plasma needed to meet the actual demand for products supplied by companies fractionating Italian plasma

\begin{tabular}{llrc}
\hline Products & $\begin{array}{l}\text { Theoretical } \\
\text { yield per kg }\end{array}$ & 2015 demand & $\begin{array}{c}\text { Plasma needed to } \\
\text { meet the demand }\end{array}$ \\
\hline FVIII and FVIII-vW $^{1}$ & $130 \mathrm{IU}$ & $137,994,500 \mathrm{IU}$ & $1,061,496 \mathrm{~kg}$ \\
Pd-FIX $^{2}$ & $256 \mathrm{IU}$ & $12,367,700 \mathrm{IU}$ & $48,311 \mathrm{~kg}$ \\
PCC $\left(3\right.$ factors) $^{2}$ & $336 \mathrm{IU}$ & $36,562,200 \mathrm{IU}$ & $108,816 \mathrm{~kg}$ \\
AT $^{2}$ & $360 \mathrm{IU}$ & $128,888,000 \mathrm{IU}$ & $358,022 \mathrm{~kg}$ \\
Fibrinogen $^{3}$ & $0.9 \mathrm{~g}$ & $24,248 \mathrm{~g}$ & $26,942 \mathrm{~kg}$ \\
Alpha-1-antithrypsin $^{4}$ & $0.152 \mathrm{IU}$ & $23,335 \mathrm{IU}$ & $153,520 \mathrm{~kg}$ \\
\hline
\end{tabular}

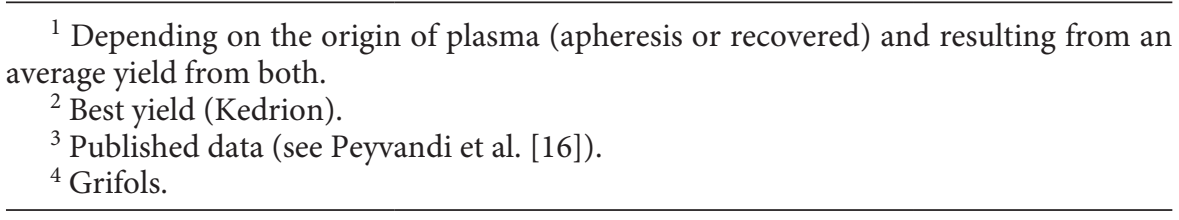

\section{Intravenous and Subcutaneous Ig}

Although also rapidly increasing in Italy, the use of Ig is consistent with the European average (76 g/1,000 inhabitants), but significantly lower than in the USA and Canada (approximately $200 \mathrm{~g} / 1,000$ inhabitants) [8]. At the yield of $3.7 \mathrm{~g}$ Ig per $\mathrm{kg}$ of plasma, the production was insufficient to cover use in 2015 and only $71 \%$ of Ig used in Italy came from the domestic source. New tenders resulted in a relevant increase in the yield of Ig in plasma fractionation: it rose from 3.7 to 4.1 (RIPP), 4.9 (NAIP), and 5 (PLANET) g/kg granted at minimum by the contract, but have now reached $5.2 \mathrm{~g} / \mathrm{kg}$ in the NAIP consortium, due to the high mean protein content in plasma of Italian donors (total protein content at quality control in 2017 [mean \pm SD]: $59.05 \pm 1.31$ g/L; Friuli Venezia Giulia Regional Blood Service, Quality Control Laboratory, pers. commun.). This is probably related to the limits in frequency of donations stated by the Italian legislation (2-4 times per year for whole blood and up to 12 times per year for plasmapheresis, with a maximum of $20 \mathrm{~L}$ per year). Moreover, tenders also gave access to previously unavailable subcutaneous (Sc) formulations. Therefore, the increased yield allowed the NAIP consortium to reach self-sufficiency for Ig (with a demand of 931,743 $\mathrm{g}$ and a theoretical production of 1,013,964 g) and 77 and $64 \%$ rely on domestic plasma in the RIPP and PLANET consortia $(1,093,923 \mathrm{~g}$ demand vs. $844,875 \mathrm{~g}$ theoretical production, and 1,416,880 g demand vs. $907,680 \mathrm{~g}$ theoretical production, respectively).

Considering that the national goal is to increase plasma collection to $16-17 \mathrm{~kg} / 1,000$ inhabitants in 2020 , it is highly probable that within the next 3 years the majority of Ig used in Italy will come from national plasma, provided that a similar yield to those offered in the NAIP and RIPP consortium can be reached across the country. However, assuming an increase in Ig-IV/Sc demand in line with the international trend but at a prudential value of $110 \mathrm{~g} / 1,000$ inhabitants, we can speculate that a production of national plasma for fractionation of approximately 1 million $\mathrm{kg}$ (about $17 \mathrm{~kg} / 1,000$ inhabitants, assuming the stability of Italian population) will still be insufficient for Ig self-sufficiency in Italy.

\section{Albumin}

The extraction capability of albumin from plasma does not significantly differ among companies and $25-26 \mathrm{~g} / \mathrm{kg}$ of plasma is the common yield granted in the contracts and in the industrial processes [9]. Actual production of 
albumin in Italy would be in line with the average use of the product in the European Union, and it would also benefit from the increased plasma collection foreseen for 2020 (essentially required for the increased Ig demand). However, in 2015, the total and standardized demand per thousand inhabitants was, respectively, $35.4 \mathrm{t}$ and 582 $\mathrm{g} / 1,000$ inhabitants, confirming that Italy is the primary consumer in the world of this protein, and its domestic production covers only $60 \%$ of demand. Thus, although the world albumin market is expected to grow until 2020, with an annual rate of between 3\% (Europe) and 7\% (Asia) [10], in Italy albumin demand will hopefully decrease (the standardized total albumin demand in 2015 was $-2.6 \%$ compared to 2014 ).

Moreover, the national plan for self-sufficiency states that "a use of albumin exceeding $400 \mathrm{~kg} / \mathrm{million}$ inhabitants must be considered inappropriate" [5] and actions are required from the health authorities to set the use below this limit. To ensure this result, a clinical audit on plasma product utilization must become common practice, to promote the appropriate demand of products. Whenever projects aiming at monitoring albumin demand have been implemented, use of albumin fell from more than 400 to less than $300 \mathrm{~kg}$ per million inhabitants [11], thus allowing albumin self-sufficiency. At present, this goal has been reached in the NAIP consortium, whose regions have now more than $95 \%$ sufficiency of albumin from domestic production. Therefore, it is our opinion that the combination of an increased plasma collection and strict control on appropriate use could provide selfsufficiency for albumin in Italy.

\section{Plasma-Derived FVIII}

Data from different official sources [7, 12] (therapeutic prescriptions or drug distribution, both from the National Health Institute) estimate the 2015 demand for FVIII (recombinant + plasma derived) was in a range from $528,695,250 \mathrm{IU}$ (9 IU per capita) to 575,000,000 IU (9.4 IU per capita); between 22 and $26 \%$ of these amounts is of plasmatic origin, with a decrease of $6 \%$ from 2014 . However, these data include products used in the treatment of both FVIII and von Willebrand factor deficiency. Due to the fact that almost all plasma fractionated in Italy is suitable for the production of labile proteins, with a yield of $150 \mathrm{IU} / \mathrm{kg}$ from apheresis plasma and $110 \mathrm{IU} / \mathrm{kg}$ from recovered plasma (minimum granted by all fractionators), it is clear that the potential for plasma-derived FVIII (pd-FVIII) is still insufficient to meet the national need $(137,994,500$ IU demand vs. $102,000,000$ IU theoretical production). However, considering that all therapeutic options must be guaranteed to patients, pd-FVIII cannot be a driver for plasma collection because of the impossibility of covering the entire broad spectrum of $\mathrm{pd}$ FVIII preparations using domestic plasma as a source.
This explains why in recent years we faced a surplus in cryo-intermediate production, which was not further manufactured into finished product, while buying pdFVIII on the market from producers other than the national fractionator.

However, extended half-life products, a bispecific antibody mimicking the coagulation function of FVIII and inhibition of anticoagulation proteins with antibodies (emicizumab, concizumab), aptamers, or RNA interference technology (fitusiran), are likely to change hemophilia A treatment $[13,14]$ and pd-FVIII will not be a first-choice therapy in Italy in the coming years $[14,15]$. Yet the debate on a potentially higher immunogenicity of r-FVIII compared to pd-FVIII is still going on, as demonstrated by the recently published SIPPET study results [16].

The need for plasma-derived Factor IX (pd-FIX) is rather low and, at a yield of $256 \mathrm{IU} / \mathrm{kg}$ (as granted by Kedrion), few lots of production are needed to satisfy the national demand of $12,367,700 \mathrm{IU}$ (corresponding to 0.2 IU per capita), from a total demand, registered in 2015, of $59,709,450 \mathrm{IU}, 79 \%$ of which was covered by recombinant products. At present, although for different reasons, there is an unnecessary accumulation of both pd-FVIII and FIX, but, since the Italian legislation prohibits the sale of products sourced from VNRDs, this renews the question of how to manage the surplus of these medicines, and their destiny is not clear, outside international cooperation.

Demand for prothrombin complex concentrates (PCC) increased by $45 \%$ in the period from 2011 to 2014, but a small decrease was shown in $2015(-2.2 \%)$, with a total demand of $36,562,200 \mathrm{IU}$, corresponding to $0.6 \mathrm{IU}$ per capita. The majority of Italian plasma meets the criteria required by the European Pharmacopeia for the production of labile proteins; hence, national self-sufficiency for this product is ensured also from the volume of plasma collected in any of the four partnerships of regions taking over the duty for the entire country. A major drawback is the fact that, at present, the only available product from contract manufacturing is a 3-factor PCC, containing FII, FIX, and FX, while the 4-factor PCC (with FVII) production is not included in any contract currently in place, thus necessitating in 2015 the provision from the market of 5,526,500 IU of this product (0.1 IU per capita).

Like albumin, there is a very high (and hardly justified) antithrombin (AT) demand: with 2 IU per capita in 2015, Italy is one of the highest consumers in the world and the national plan for self-sufficiency mandates the decrease to 1 IU per capita, clearly considering the present use as mainly inappropriate. Nevertheless, plasma for labile proteins production collected in just one partnership of regions would have the potential, at a yield of $360 \mathrm{IU} / \mathrm{kg}$, to meet all national needs for AT, even in the presence of this very high demand. 
Considering other products, the use of fibrinogen and alpha-1-antithrypsin is rather low and their demand can be completely satisfied with a small amount of the internal production. For this reason, from 50,000 up to 200,000 $\mathrm{kg}$ of plasma (depending on the yield) would be sufficient to meet the 2015 demand registered in Italy for both proteins [17]. This remains true even considering that the use of fibrinogen is largely increasing in patients with major bleeding as part of multimodal therapy involving other treatments for coagulopathy [18], also bearing in mind that cryoprecipitate prepared by blood establishments is not in use in Italy [19]. Other low-volume or special products such as, for instance, anti-D Ig or C1 esterase inhibitor, come from proprietary technologies, or, due to the economies of scale or to intellectual rights of property issues, are manufactured by only one or a few producers. If the medicine is not present in the portfolio of the company awarded the tender, only the market can meet the internal demand.

\section{Product Exchange among Regions}

\section{"Pay the Products"}

The possibility of exchanging products coming from contract manufacturing among regions is laid down in an "ad hoc" agreement between the state and the regions [20] and the process for this is simple: regions needing PDMPs from toll manufacturing can access the warehouses of other regions with surplus products and buy them, at a maximum amount defined by the proprietary region and following a yearly defined plan. A governmental office calculates the debits (or the credits) of the regions, which are then subtracted (or added) to the healthcare budget given by the state to each region. Fees for the products are as follows: albumin $1.9 \mathrm{EUR} / \mathrm{g}$, Ig 35 EUR/g, pd-FVIII $0.23 \mathrm{EUR/IU,} \mathrm{pd-FIX} 0.23 \mathrm{EUR/IU,}$ PCC (3 factors) 0.24 EUR/IU, and AT 0.225 EUR/IU. The economic values of the products might differ from those calculated in other countries; they are defined by the same agreement among the state and the regions based upon an "ad hoc" study aimed at defining an average cost for plasma production [20]. The results of this study are in good agreement with several analyses of the Italian cost of plasma for fractionation recently published [21-23].

\section{"Pay the Process"}

In a few cases, an agreement has been made among regions with a surplus of intermediates and others lacking a product: the intermediate of the process has been gifted by the surplus regions, while the regions with inadequate supply pay the pharmaceutical company only for the production process, thus accessing, at a low cost, the final product although lacking the raw material. This can be a solution for the use of otherwise accumulating intermediates of a process where the target is the driving product.

\section{Discussion}

According to Italian law, "self-sufficiency in the supply of blood and blood derivatives is a national objective aimed at guaranteeing that the quality and safety of transfusion therapy is the same for all citizens" and is based "on voluntary, periodic, responsible, anonymous, and gratuitous donations of human blood" [1]. Self-sufficiency should only refer to the appropriate demand, based on therapeutic needs related to clinical evidence [11, 23]; hence, monitoring of plasma product utilization and plans for plasma collection aimed at national self-sufficiency are published and regularly updated by the national competent authorities [5]. Moreover, PDMPs from plasma collected by the public transfusion system in Italy can only be supplied by authorized third-party companies $[1,2]$, fractionating Italian plasma in a contract manufacturing agreement where plasma, intermediates, products, and by-products always remain a property of the regions and cannot be sold outside the national health system. A rational and priority use of medicines from national production is also promoted by the law [5].

At present, contract manufacturing in Italy is experiencing promising developments. Before the possibility of competition among companies, many limits affected the vitality of toll manufacturing: there was no possibility to access different technologies for improving the yield of some products (namely Ig), there was a unique portfolio of products, the exchange among regions was limited to a few surplus products, and there was no cost competition for the service, thus limiting the exploitation of the therapeutic potential of plasma from VNRDs. With the opening to competition, an improvement in the national selfsufficiency program took place.

The national health service now has access to a wider portfolio of PDMPs manufactured from plasma of Italian VNRDs. Over recent years, the plasma protein industry has developed a wide range of products for the treatment of specific groups of patients. If the availability of these products is limited by the scarcity of plasma, then the use of domestic plasma from VNRDs in several industrial processes offers patients the right of accessing many products (or different pharmaceutical preparation of the same product) which would otherwise need a regular supply from the market [24]. Moreover, dividing the production among different companies prevents the risk of a possible nationwide interruption of plasma fraction- 
ation in the case of problems at a fractionation plant, thus preventing the possibility of a "shortage," in the sense of the definition made by the Food and Drug Administration (FDA): a product shortage occurs when a product is not available in sufficient quantity to meet the demand [25].

Probably the most important result is the increased yield in driving proteins (mainly Ig) obtained with the tenders. It should be remembered that globally Ig represents over $50 \%$ of total expenditure for PDMPs, and their demand, in contrast to other PDMPs, is constantly and decisively increasing for many indications [26], with even worrying predictions in terms of the capability to guarantee the amount of plasma needed for the industrial process.

With regard to albumin (the other driving product in Italy), the national demand would already be satisfied by the actual production, provided that criteria for an appropriate clinical use are applied, but the present use is so high that domestic production covers only $60 \%$ of the need. Therefore, the national plasma plan, requiring the development of clinical audit programs for the promotion of a rational use of this product, must be actively implemented in clinical practice. This is also true for other products (e.g., AT), although the potential production in this case is not a limit to the supply.

For all other PDMPs, the most relevant outcome of the tenders is the possibility that any of the four partnerships of regions can take over the task of production of one protein (or one medicinal product of a defined brand) to meet the national demand. A critical mass of plasma between 150,000 and 250,000 kg per year is in line with the availability of accessory products in the amount required yearly in clinics for pd-FVIII/von Willebrand factor (one brand product), pd-FIX, PCC, AT, fibrinogen, and alpha1-antithrypsin. In this respect, it is urgent that, at the national level, economic values of the different products are updated to include PDMPs not present yet, in order to allow the regions to plan a surplus production of PDMPs for mutual exchange.

There is still a limit to the full exploitation of the potential coming from the national plasma supply, represented by the prohibition, stated by Italian legislation, against the possibility of domestic plasma being fractionated in countries which allow the collection of plasma from paid donors. This has been justified in order to avoid the potential cross-contamination of plasma from paid donors versus VNRDs, but such a constraint limits the competition and the portfolio of possible products from national plasma. Without entering the debate on the safety of plasma from paid donors versus VNRDs, some caution must be noted which raise criticism against this limitation in Italian toll fractionation. Firstly, if the possible cross-contamination between paid and VNR donations is a concern, then no plant should be exempt from this risk: all the plants (including those located in Italy), no matter the local jurisdiction on VNRDs, fractionate plasma from paid donations bought on the international (mainly US) market or collected from remunerated donors by the same companies in their own plasmapheresis centers. Secondly, in western countries (including Italy) patients are receiving, without any health prejudice, products sourced from both paid donors and VNRDs, for the evident reason that plasma from VNRDs is not collected in sufficient volumes to meet all the demand. If we accept all these products, it seems appropriate to also admit for the fractionation of domestic plasma all plants where they are manufactured. As concluded by the Dublin consensus statement, cooperation between blood establishments and the plasma industry is important to ensure that the best community outcomes are achieved, including sufficiency of supply for patients [27].

\section{Conclusions}

Due to the ethical principle on self-sufficiency stated by the Italian legislation, ideally all PDMPs should come from domestic plasma collection. However, for many reasons, this is unpractical and even unfeasible; thus, the concept of "self-sufficiency" must be further specified to guarantee a proper utilization of national plasma, an ethical use of the donations, an appropriate clinical use of plasma products, an adequate provision of medicines to patients and, finally, a cost-effectiveness of the national plasma program [28].

We can therefore regard self-sufficiency in plasma for fractionation as the capability of systematically guaranteeing to patients the prompt and continuous availability of a defined set of PDMPs, aligned with patients' appropriate needs, through the national collection of plasma for fractionation from VNRDs, in compliance with the existing regulatory framework. Nevertheless, the country's self-sufficiency in PDMPs is to be complemented by the contribution from the commercial market, for both products for which plasma collected is insufficient (and any further increase would be unpractical) and medicines not produced by the companies running the toll manufacturing service. However, most importantly, opening the competition among different companies for domestic plasma toll fractionation has the potential to make significant progress toward self-sufficiency of PDMPs from VNRDs in Italy. 


\section{Acknowledgments}

We wish to thank Prof. Hans Erik Heier (Oslo, Norway) and Dr. Stefania Williams (Newcastle-upon-Tyne, UK), for helpful criticism in reading the manuscript.

\section{Disclosure Statement}

The authors declare the absence of any conflict of interest in relation to this paper.

\section{References}

1 Centro Nazionale Sangue. Legge 21 ottobre 2005, n. 219. Nuova disciplina delle attività trasfusionali e della produzione nazionale degli emoderivati. 2017 Oct 31.

2 Ministero della salute Decreto 5 dicembre 2014. Individuazione dei Centri e aziende $\mathrm{d}$ frazionamento e di produzione di emoderivati autorizzati alla stipula delle convenzioni con le regioni e le province autonome per la lavorazione del plasma raccolto sul territorio nazionale. Rome: Ministero della salute; 2014.

3 Ministero della salute Decreto 12 aprile 2012. Schema tipo di convenzione tra le regioni e le province autonome e le aziende produttrici di medicinali emoderivati per la lavorazione del plasma raccolto sul territorio nazionale. Rome: Ministero della salute; 2012.

4 Centro Nazionale Sangue [Internet]. Monitoraggio plasma [cited 2018 Nov 5]. Available from: http://www.centronazionalesangue.it/ monitoraggio-plasma.

5 Ministero della Salute Decreto 02 dicembre 2016. Programma nazionale plasma e medicinali plasmaderivati, anni 2016-2020. Rome: Ministero della salute; 2017 Jan 12.

6 World Federation of Hemophilia. Contract for fractionation. 3rd ed. Facts and Figures. Montreal: WFH; 2008.

7 Candura F, Calizzani G, Profili S, Chelucci C, Brutti C, Biffoli C, et al. Analisi della domanda dei principali medicinali plasmaderivati in Italia. 2015. Rapporti ISTISAN 17/20. Rome: Istituto Superiore di Sanità; 2017.

8 Robert P. International developments: facts and figures. Why is the plasma products market growing? International Plasma Proteins Congress, 2017 Mar 14-15; Prague, Czech Republic.

9 Raoufinia R, Mota A, Keyhanvar N, Safari F, Shamekhi S, Abdolalizadeh J. Overview of Albumin and Its Purification Methods. Adv Pharm Bull. 2016 Dec;6(4):495-507.

10 Bult JM. The world needs plasma: global perspective and dynamics. Views for potential solutions. International Plasma Protein Congress, 2018 Mar 13; Budapest, Hungary.

11 De Angelis V, Tillati S. Monitoring the appropriate use of plasma products. In: Heier
HE, Burnouf T, De Angelis V, El Ekiaby M, editors. Proceedings of the ESTM residential course on Appropriate Use of Plasma Products. 2012 Nov 14-18; Zagreb, Croatia. p. 331-6.

12 Abbonizio F, Giampaolo A, Arcieri R, Hassan $\mathrm{HJ}$; Associazione Italiana Centri Emofilia (AICE). Registro Nazionale Coagulopatie Congenite. Rapporto 2015. Rome: Istituto Superiore di Sanità; 2017.

13 Balkaransingh P, Young G. Novel therapies and current clinical progress in hemophilia A. Ther Adv Hematol. 2018 Feb;9(2):49-61.

14 Franchini M, Mannucci PM. Non-factor replacement therapy for haemophilia: a current update. Blood Transfus. 2018 Sep;16(5):45761.

15 Pasca S, De Angelis V, Milan M, Zanon E. Can the plasmaderived factor VIII still play a role in the treatment of acquired hemophilia $\mathrm{A}$ at the time of new drugs? Blood Coagul Fibrinolysis. 2018 Jul;29(5):417-22. ; Epub ahead of print.

16 Peyvandi F, Cannavò A, Garagiola I, Palla R, Mannucci PM, Rosendaal FR; sippet study group. Timing and severity of inhibitor development in recombinant versus plasma-derived factor VIII concentrates: a SIPPET analysis. J Thromb Haemost. 2018 Jan;16(1):3943.

17 Grifols [Internet]. Investors Meeting. May 27th-28th, 2010 [cited 2018 Mar 17]. Available from: https://www.grifols.com/documents/10192/86372/04 iam-2010e n / 956094 b 3 - 1 f 4 c - 4 d 74 - 87 b 8 d8038d10db50.

18 Godier A, Greinacher A, Faraoni D, Levy JH, Samama CM. Use of factor concentrates for the management of perioperative bleeding: guidance from the SSC of the ISTH. J Thromb Haemost. 2018 Jan;16(1):170-4.

19 Catalano L, Piccinini V, Facco G, Gentili S, Marano G, Pupella S, et al. Attività del sistema trasfusionale italiano (2015). Rapporti ISTISAN 16/38. Rome: Istituto Superiore di Sanità; 2016.

20 Accordo Stato-Regioni concernente. Indicazioni in merito al prezzo unitario di cessione tra aziende sanitarie e tra Regioni e Province autonome delle unità di sangue, dei suoi componenti e dei farmaci plasmaderivati prodotti in convenzione. 2015 Oct 20. Available from: https://www.centronazionalesangue.it/ node/95.

21 Grazzini G, Ceccarelli A, Calteri D, Catalano L, Calizzani G, Cicchetti A. Sustainability of a public system for plasma collection, contract fractionation and plasma-derived medicinal product manufacturing. Blood Transfus. 2013 Sep;11 Suppl 4:s138-47.

22 Eandi M, Gandini G, Povero M, Zaniolo O, Pradelli L, Aprili G. Plasma for fractionation in a public setting: cost analysis from the perspective of the third-party payer. Blood Transfus. 2015 Jan;13(1):37-45.

23 Aprili G. How to make plasmapheresis more efficient: a study model. Blood Transfus 2016; 14(Suppl 2): s81-2.

24 C-C/EAHC-EU Commission [Internet]. An EU-wide overview of the market of blood, blood components and plasma derivatives focusing on their availability for patients. Creative ceutical report revised by the Commission to include stakeholders' comments [cited 2018 Mar 18]. Available from: https://ec.europa.eu/health//sites/health/files/blood_tissues_organs/docs/20150408_cc_report_ en.pdf.

25 US Food and Drug Administration [Internet]. CBER-regulated products: shortages and discontinuations [cited 2018 Mar 18]. Available from: http://www.fda.gov/BiologicsBloodVaccines/SafetyAvailability/Shortages/default.htm.

26 Perez EE, Orange JS, Bonilla F, Chinen J, Chinn IK, Dorsey M, et al. Update on the use of immunoglobulin in human disease: A review of evidence. J Allergy Clin Immunol. 2017 Mar;139(3 3S):S1-46.

27 O'Mahony B, Turner A. The Dublin Consensus Statement 2011 on vital issues relating to the collection and provision of blood components and plasma-derived medicinal products. Vox Sang. 2012 Feb;102(2):140-3.

28 De Angelis V, Breda A. Plasma-derived medicinal products self-sufficiency from national plasma: to what extent? Blood Transfus. 2013 Sep;11 Suppl 4:s132-7. 